International Journal of Automotive and Mechanical Engineering (IJAME) ISSN: 2229-8649 (Print); ISSN: 2180-1606 (Online);

Volume 13, Issue 3 pp. 3788 - 3811 December 2016

OUniversiti Malaysia Pahang Publishing

DOI: https://doi.org/10.15282/ijame.13.3.2016.20.0310

\title{
Current trends on combustion control methods using fuel reactivities
}

\section{Ram Kishore Sankaralingam and T. Venugopal*}

\author{
School of Mechanical and Building Sciences, VIT University \\ Vandalur - Kelambakkam road, Chennai - 600127, India. \\ *E-mail: venugopal.t@vit.ac.in \\ Phone: +919865705078
}

\begin{abstract}
Compression ignition (CI) engines are used in heavy duty engine applications due to their high torque capability and thermal efficiency. However, high NOx and smoke emissions are the challenges in using $\mathrm{CI}$ engines. Homogeneous charge compression ignition (HCCI) is one of the best methods to reduce NOx and smoke emissions. However, controlling the combustion for an entire range of operation in HCCI mode is a challenging task. Different methods like fast thermal management (FTM), exhaust gas recirculation (EGR), turbo charging and reactivity controlled compression ignition (RCCI) are reviewed and discussed in this article. RCCI is similar to HCCI, which uses reactivities of two different fuels to control combustion. The combustion objectives of HCCI such as less NOx and soot emission can also be obtained through this method. Combustion control based on reactivities of various fuels (RCCI) is discussed significantly. Fuels that have different reactivities can help to control the combustion phasing and thereby reducing the emission. Two different fuels can be injected together into the manifold or one fuel can be injected in the port and other in the combustion chamber directly for reactivity based combustion control. The technological development in different combustion control methods is reviewed and discussed in this article which is a useful knowledge base for further research investigations. When compared to other combustion control methods, RCCI is found to be advantageous in all perspectives such as cost, flexibility in control, simplicity and wide range of operation.
\end{abstract}

Keywords: HCCI; RCCI; CA50; Ignition delay; NOx.

\section{INTRODUCTION}

Diesel Engines are contributing much towards transportation and power generation applications. Despite their advantages, they usually emit high NOx and soot emissions. By a successful implementation of Homogenous Charge Compression Ignition (HCCI) to conventional Diesel engine, NOx and soot emissions can be reduced to a greater extent [1-5]. HCCI engines also have other disadvantages like lack in combustion phasing, narrow operating range and high $\mathrm{HC}$ emissions at low loads, etc. [6-9]. There are various combustion control methods reported like Variable Compression Ratio (VCR), Exhaust Gas Recirculation (EGR) and Fast Thermal Management (FTM) [10-12]. Many challenges have to be overcome to implement the above methods like complex mechanism, charge dilution, delayed ignition, frequent data monitoring and high cost etc. One of the pioneering methods under the current research is Reactivity Controlled Compression Ignition (RCCI) engines to overcome the above challenges. This concept uses two fuels (dual fuels) of different reactivities to control combustion. RCCI uses two 
different fuels, namely low reactive fuel (LRF) and high reactive fuel (HRF). Generally, LRF is injected in the manifold whereas the HRF is injected directly into the cylinder [13]. Combustion starts with the auto ignition of HRF and air followed by the combustion of LRF and air [14]. The self-ignition temperatures have to be considered previously before selecting the fuels. Another method in the RCCI concept is injecting the two fuels in the intake manifold which produces an almost uniform air-fuel mixture inside the cylinder $[13,15]$. Considerations about other factors like the engine's compression ratio, fuel's octane number and cetane number are also important in implementing the RCCI concept. This concept has been investigated and reported by different literature widely after the 20th century. This article was attempted in order to compile the technological developments and results reported in RCCI literature which will be a useful knowledge base for further investigations on combustion control using fuel reactivities in HCCI engines.

\section{METHODS AND MATERIALS}

\section{Homogeneous Charge Compression Ignition}

The air-fuel mixture in CI engine is heterogeneous in nature. The main difference between CI and HCCI mode of operation is the air-fuel mixture is homogeneous throughout the cycle of operation in the case of HCCI engines. This mixture gets automatically ignited when the auto ignition temperature for the fuel is reached at the end of compression [16-19]. It uses premixed charge similar to spark ignition (SI) engines and gets its compression ignited similar to CI engines which favour its operation at high compression ratios with low NOx emissions [19-23]. This engine generally has less fuel consumption at part load conditions, making it better than SI and CI engines [24]. A well-mixed fuel-air mixture obtained favours the absence of fuel rich region, thus avoiding high temperatures being created and thereby producing low NOx and soot emissions [25]. High temperatures and pressure favour the NOx formation [26]. However, in the case of HCCI operation, the peak temperature and heat release rate have low value due to the uniform mixture distribution and as a result, a good reduction in NOx and soot are obtained. The combustion process in HCCI mode of operation is as shown in Figure 1.
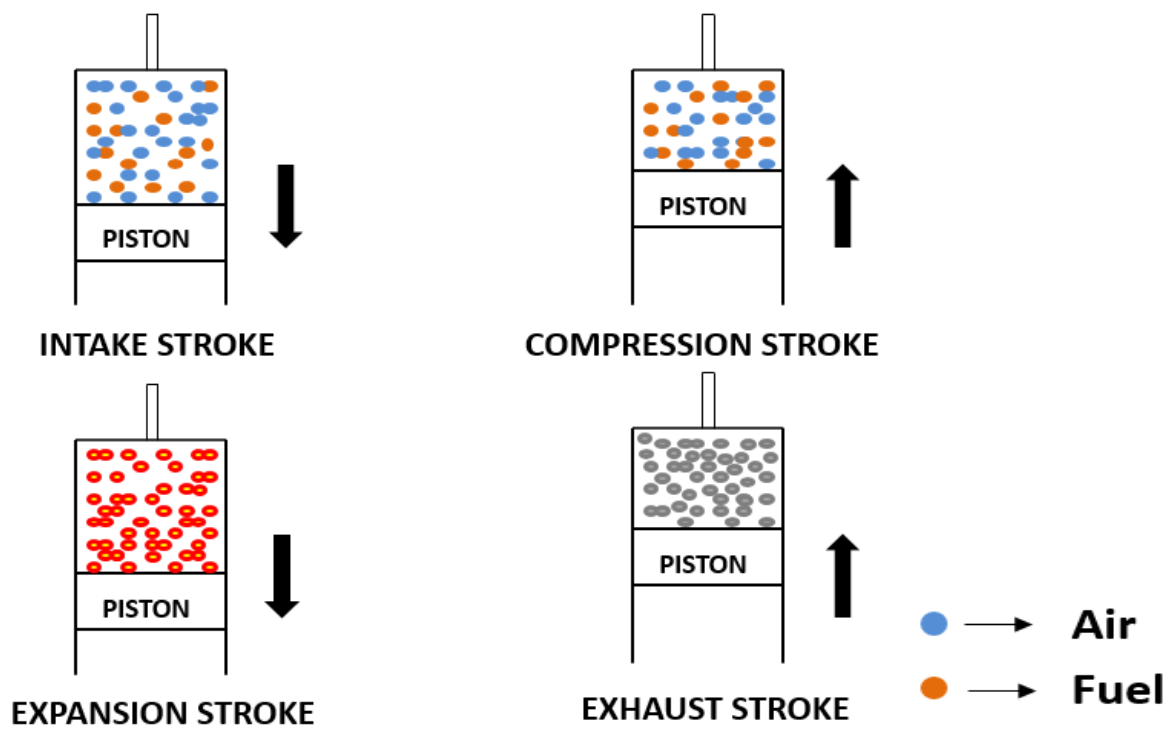

Figure 1. HCCI Combustion process. 


\section{Combustion Control in HCCI}

\section{Varying the Compression Ratio}

Compression ratio of an engine is defined as the ratio of total volume (stroke volume + clearance volume) to clearance volume. Generally, when compression ratio increases, thermal efficiency will increase [27]. However, combustion phasing (occurrence of peak pressure and/or crank angle at which $50 \%$ of fuel mass burn takes place) [28] always affect the load range and efficiency of HCCI operation when varying the compression ratio. Ignition delay is the most important parameter in controlling the combustion process in CI and HCCI engines. It is the time lag between the start of injection of fuel to the start of ignition in CI engines. However, in HCCI mode, ignition delay is calculated based on the maximum pressure difference $\left(\mathrm{dP}_{\max }\right)$. It is the time taken for $\mathrm{dP}$ value to reach $20 \%$ of $\mathrm{dP}_{\max }$ [29]. Longer ignition delay period increases the peak pressure and temperature inside the cylinder which leads to high NOx emission and knocking of the $\mathrm{CI}$ engine. This is due to higher fuel accumulation during the longer ignition delay period and thereby sudden burning of fuel occurs during the initial phase of the combustion. However, HCCI operation prefers high ignition delay periods, especially for high load operations to avoid knocking unlike CI engines. At high loads, the cylinder gas temperature is high which leads to better evaporation of the fuel. This reduces the ignition delay period [30, 31]. The combustion is advanced at high load conditions due to faster vaporisation of fuel and high in-cylinder temperatures. Furthermore, this may cause the engine knock at high loads [32]. This is because multiple ignitions occur in HCCI operation, i.e. all the fuels at different portions of the cylinder burns at a time which increases the cylinder pressure abruptly.

To avoid knock at high load operation, the ignition delay should be high in HCCI operation. It was reported that by decreasing the compression ratio, the start of ignition can be delayed in such a way that the engine can be operated without knock [33, 34]. The compression ratio can be decreased by increasing the clearance volume, which is the volume between the piston head and cylinder head [10]. This reduces the rise in temperature with respect to compression, thus delaying the ignition. At part loads, the cylinder gas temperature is less which leads to delayed ignition (late combustion). To avoid misfire at the part load operation in HCCI mode, ignition delay should occur less. It was reported that the maximum Brake Mean Effective Pressure (BMEP) values (maximum torque) decrease with the increase in compression ratio when the engine is operated in HCCI mode [10]. The compression ratio can be increased by decreasing the clearance volume. This increases the rise in temperature with respect to compression, thus advancing the ignition which is favourable for part load operation. Table 1 shows the variation of combustion efficiency and NOx with compression ratio, at constant intake air temperature of $100^{\circ} \mathrm{C}$ and constant engine speed of $2000 \mathrm{rpm}$ [10].

Table 1. Variation of combustion efficiency with compression ratio and BMEP [6].

\begin{tabular}{ccccc}
\hline $\begin{array}{c}\text { Compression } \\
\text { ratio }\end{array}$ & $\begin{array}{c}\text { BMEP } \\
\text { (bar) }\end{array}$ & Lambda & $\begin{array}{c}\text { Combustion } \\
\text { Efficiency } \%\end{array}$ & $\begin{array}{c}\text { NOX } \\
(\mathrm{g} / \mathrm{kWh})\end{array}$ \\
\hline 17 & 1 & 4 & 78.5 & 0.04 \\
16.5 & 1.4 & 3.8 & 82.5 & 0.03 \\
16.3 & 1.7 & 3.6 & 88 & 0.04 \\
15.7 & 2.1 & 3.4 & 90 & 0.05 \\
14 & 3 & 2.6 & 94 & 0.07 \\
\hline
\end{tabular}


The combustion efficiency is increased with the decrease in compression ratio and increase in BMEP. When the compression ratio is decreased, the ignition is delayed [33], [35]. Delayed ignition for high load led to knocking less combustion and high combustion efficiency. At low load, the combustion efficiency remained less at high compression ratio. This is because, leaner combustion with cold intake air at low BMEP has increased the $\mathrm{CO}$ emission, which resulted in less combustion efficiency [10]. Varying the compression ratio frequently in a conventional engine is difficult. VCR engine can vary its compression ratio frequently. The axis of crank angle rotation is shifted to different positions for increasing or decreasing the clearance volume. Hence, by varying the compression ratio of the engine, the efficiency of HCCI mode can be increased in the entire range of load of operation.

\section{Exhaust Gas Recirculation}

Recirculating or retaining the part of the exhaust gas inside the cylinder's so-called exhaust gas recirculation (EGR) is generally used to reduce the in-cylinder temperature. It is done by increasing the specific heat capacity of in-cylinder charge (air + fuel + exhaust gas) by admitting more $\mathrm{CO}_{2}$ through EGR [36-38]. Exhaust Gas Recirculation can be done in two ways. Part of the exhaust gas is taken from the exhaust port through a tube and it is supplied to the intake manifold with or without intercooling. This method is called as external EGR which is shown in Figure 2. The second method is retaining the exhaust gas by varying the exhaust valve opening (EVO) time. This method is called as internal EGR [37, 39]. Generally, closing the exhaust valve earlier leads to increasing the percentage of exhaust gas retained inside the cylinder.

EGR favours the combustion phasing (retard) that helps engine to operate with high loads without knock. It also controls the peak rate of heat release and thereby the in-cylinder gas temperature to reduce the NOx formation [33, 40-42]. However, charge dilution by EGR could also lead to increase in HC emissions. This is one of the challenges to be overcome, particularly at high EGR rate. It was reported that when the rate of EGR increases, the combustion gets retarded slowly and thereby reducing the in-cylinder temperature and NOx emission. On the other hand, if EGR is done by advanced closing of the exhaust valve, it favours the advanced combustion phasing. The heat retained in the cylinder due to exhaust gas favours earlier combustion $[11,43]$.

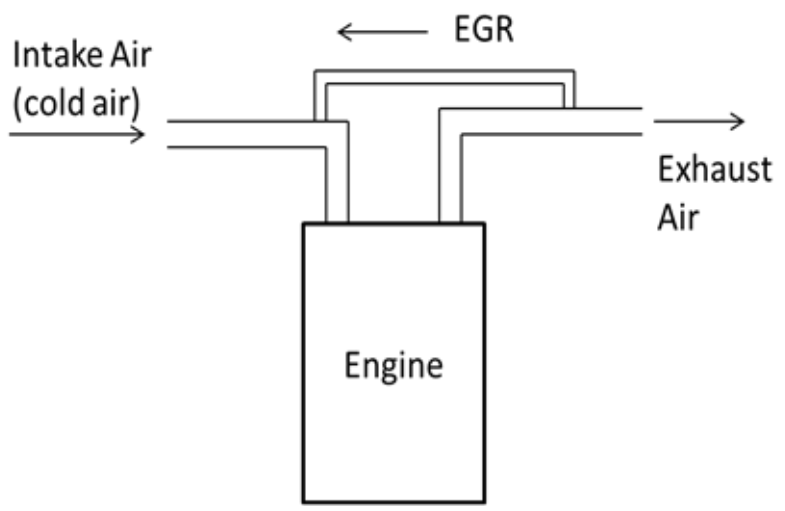

Figure 2. EGR setup [35].

Table 2 shows the variation CA50, indicating the mean effective pressure (IMEP) and thermal efficiency for different EGR rates [11]. EGR rate is the ratio of mass of 
external and re-breathed EGR to the mass of intake charge. Test results were reported at a constant speed of $1500 \mathrm{rpm}$ and constant mass of charge. Intake charge is taken as a mixture of air, fuel, external EGR (EEGR) and re-breathed EGR (REGR) which is also called as internal EGR.

Table 2. Variation of CA50 with respect to EGR rate [7].

\begin{tabular}{ccccc}
\hline $\begin{array}{c}\text { EGR Throttle } \\
\text { Opening (deg) }\end{array}$ & $\begin{array}{c}\text { EGR } \\
\text { Rate \% }\end{array}$ & $\begin{array}{c}\text { CA50 } \\
\text { (ATDC) }\end{array}$ & $\begin{array}{c}\text { IMEP } \\
\text { (MPa) }\end{array}$ & $\begin{array}{c}\text { Thermal } \\
\text { Efficiency \% }\end{array}$ \\
\hline 0 & 40 & -4 & 0.384 & 36.2 \\
5 & 42 & -3 & 0.386 & 36.4 \\
10 & 45 & -2 & 0.391 & 37 \\
15 & 49 & -1 & 0.400 & 37.8 \\
20 & 54 & 0 & 0.402 & 38 \\
25 & 58 & 4 & 0.416 & 38.5 \\
30 & 60 & 8 & 0.420 & 38.8 \\
\hline
\end{tabular}

It was reported that crank angle values at which $50 \%$ of heat release takes place (CA50) increases (delayed or retarded combustion) with EGR rate. This is due to the increase in specific heat capacity of the intake charge with EGR rate, which resulted in a delayed ignition. The thermal efficiency and IMEP are reported to be high $(38.8 \%$ and $0.42 \mathrm{MPa})$ at retarded CA50 ( $\left.8^{\circ} \mathrm{ATDC}\right)$ (Table 2$)$. Hence, by using EGR at high loads, combustion is retarded which results in knocking less combustion and high thermal efficiency [11]. It can be concluded that the method followed for charge dilution (i.e. external EGR or internal EGR by varying the EVO) leads to different trends in combustion phasing in HCCI operation.

\section{Fast Thermal Management}

Fast Thermal Management is a type of combustion control that varies the inlet air temperatures frequently based on the required combustion phasing. This method has two air inlets; one for hot air and the other for cold air as shown in Figure 3. The exhaust gas heat is recovered using a heat exchanger and used for generating the hot air. The normal atmospheric air is taken as cold air [12]. Based on the CA50 requirements, the hot and cold air proportions are decided. However, adding heat exchanger to the exhaust may lead to back pressure. This will give rise to a decrease in engine power. Use of a PID controller to monitor the IMEP will reduce this effect by regulating the fuel consumption.

Table 3 shows the variation of CA50 (ATDC) with respect to the intake air temperature with a constant indicated mean effective pressure of 2 bar [12]. As the intake charge temperature is increased, the temperature rise is rapid during compression which helps in achieving the self-ignition temperature of intake charge at the early crank angles. Table 3 shows that increasing the intake temperature has led to advanced combustion. Increase in CA50 values leads to delayed ignition and decrease in CA50 values leads to advanced ignition. This adverse effect of CA50 on ignition delay can be used to improve the operating range of HCCI to different extremes, along with high thermal efficiency. 
Table 3. Variation of CA50 with intake air temperature [8].

\begin{tabular}{|c|c|}
\hline $\begin{array}{l}\text { Intake charge } \\
\text { Temperature }{ }^{\circ} \mathrm{C}\end{array}$ & $\begin{array}{c}\text { CA50 } \\
\text { (ATDC) }\end{array}$ \\
\hline 170 & 9 \\
\hline 172 & 9 \\
\hline 175 & 7.5 \\
\hline 180 & 5.5 \\
\hline 182 & 4 \\
\hline 188 & 1 \\
\hline
\end{tabular}

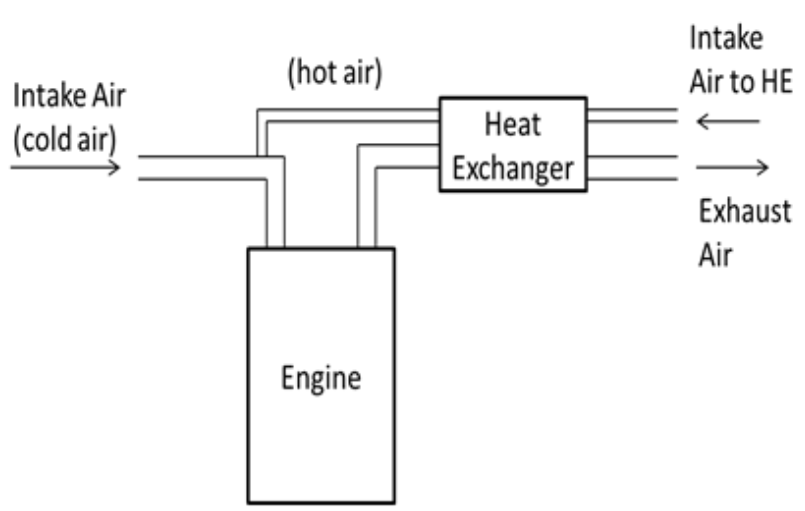

Figure 3. Fast thermal management [8].

\section{Super Charging or Turbo Charging}

Misfiring at low load and knocking at high load conditions are the major challenges facing the HCCI mode operation. This restricts the load range of operation of HCCI engines as compared to conventional CI engines. The load range of HCCI mode can be increased with Supercharging or Turbocharging by increasing the IMEP and rising the intake pressure [33]. The high pressure gas from the exhaust expands in the Turbine and drives it. This turbine drives the compressor coupled directly with it [44, 45]. The compressor increases the intake air pressure and thereby the combustion pressure. The purpose of turbo charger is to improve the volumetric efficiency [46]. The arrangement of a typical turbocharger is shown in Figure 4. Turbo charger outputs are based on the nature of exhaust gas. If the exhaust gas pressure is high, it results in a high speed operation of turbo coupled with the compressor. Thus, a huge mass of air at high pressure gets into the intake manifold, increasing the volumetric efficiency and evaporation of fuel $[47,48]$. Increasing the intake boost pressure shortens the ignition delay [49]. Increase in intake boost pressure increases the charge temperature simultaneously. This leads to the rapid rate of rise in charge temperature during compression. Thus, intake charge attains the self-ignition temperature of fuel rapidly, which leads to advanced combustion.

Increased boost pressure increases the operating range of HCCI operation [16]. It was reported that turbo charging in HCCI increases the BMEP up to 14 bar [50]. Table 4 shows the variation of thermal efficiency at different intake pressure, intake temperature and BMEP values [50]. At low load (BMEP 5bar), the intake pressure (17.7 bar) and intake temperature $\left(24^{\circ} \mathrm{C}\right)$ were reported to be less. The thermal efficiency at this case was about $32 \%$. Low intake temperature and low intake pressure leads to high ignition 
delay at low loads, which results in incomplete combustion (UHC emissions $10 \mathrm{~g} / \mathrm{kWh}$ ) and hence less thermal efficiency. When the load (BMEP) increases, the intake temperate and pressure are increased, which result in high efficiency (38\%). The maximum BMEP value was reported at $1800 \mathrm{rpm}$. Thus, turbo charging in HCCI mode results in efficient high load operation with significantly less NOx emissions. Turbo charging has its limitations due to surging and choking. Surging is a condition at which the pressure after the compressor exceeds the pressure inside the compressor. This results in reverse flow of air at the inlet. Surging attributes to high turbo efficiency. However, in the case of HCCI, the overall turbo efficiency is found to be $58 \%$, which results in less surging effects [47]. Choking is a condition at which turbocharger operates at the maximum mass flow rate of air. Choking attributes to high compressor rpms. In the case of HCCI, the engine operates at low temperature combustion (LTC) which results in low exhaust gas pressure, causing low compressor rpm. The use of variable geometry turbocharger (VGT) can address these limitations effectively for a turbocharged HCCI operation.

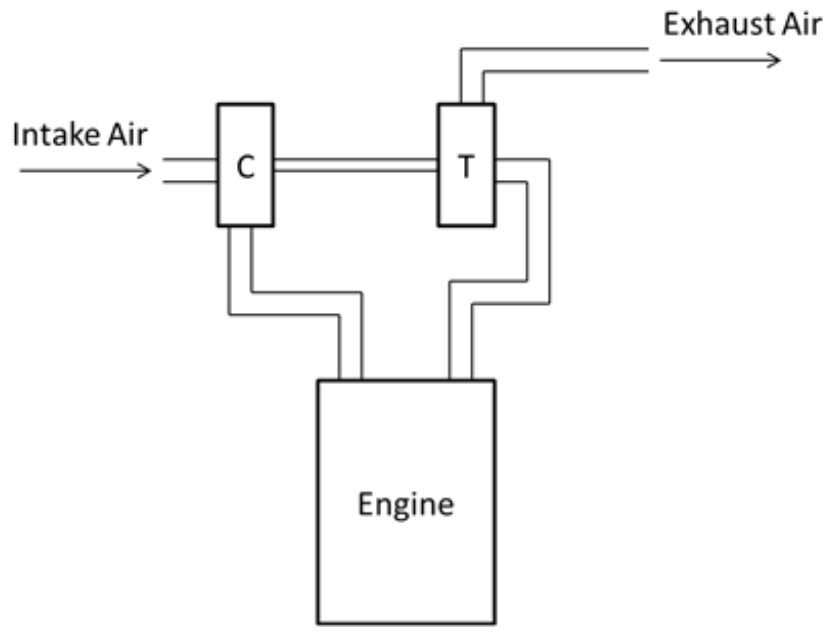

Figure 4. Turbocharging [42].

Table 4. Variation of BMEP with Intake Pressure and speed [47].

\begin{tabular}{cccccc}
\hline $\begin{array}{c}\text { Speed } \\
(\mathrm{rpm})\end{array}$ & $\begin{array}{c}\text { Intake } \\
\text { Pressure } \\
(\text { bar })\end{array}$ & $\begin{array}{c}\text { Intake } \\
\text { Temp } \\
{ }^{\circ} \mathrm{C}\end{array}$ & $\begin{array}{c}\text { BMEP } \\
(\text { bar })\end{array}$ & $\begin{array}{c}\text { NOx } \\
(\mathrm{g} / \mathrm{kWh})\end{array}$ & $\begin{array}{c}\text { Thermal } \\
\text { Efficiency } \%\end{array}$ \\
\hline 1800 & 1.7 & 24 & 5 & 0.004 & 32 \\
& 2.4 & 31.2 & 10 & 0.01 & 37 \\
2000 & 3.1 & 40 & 14 & 0.03 & 38 \\
& 2 & 30 & 5 & 0.005 & 29 \\
& 2.4 & 31.8 & 8 & 0.007 & 33 \\
& 2.7 & 40.5 & 13 & 0.047 & 35 \\
\hline
\end{tabular}

\section{Fuel Reactivity Control}

Every fuel has different combustion properties and reactions with oxygen. Supplying two fuels which have different combustion characteristics (reactivities) can be used to control the combustion phasing, combustion duration and engine knock [51-53]. This is called as Reactivity Controlled Compression Ignition (RCCI), one of the techniques used in HCCI mode. RCCI engine is similar to dual fuel engine, except in dual fuel engine pilot 
fuel which is used to initiate the combustion, whereas in RCCI, the pilot fuel proportions are varied to obtain different fuel reactivity stratifications [54]. Reactivity control can be established using Global Reactivity or Reactivity Gradient. Global reactivity depends on the type of fuel and the amount of fuel being injected, whereas reactivity gradient depends on injection strategies like early or late injection of low and high cetane fuels [55]. Generally, RCCI uses two injectors, each for one fuel. It has been reported that high efficiency, along with NOx and soot reduction, can be obtained when using higher amount of low reactive fuel [13]. High reactive fuels are used either to trigger the combustion or initiate the LRF's combustion [56]. Many methods have been reported and tried in the RCCI concept that are discussed in the following section.

\section{Reactivity of Fuel for Controlling Combustion}

\section{RCCI with a Port and Direct Injection (Single fuel)}

RCCI mode of operation needs fuels of different reactivates as mentioned earlier. High reactive fuel is generally the one that has high cetane number to initiate combustion. Low reactive fuel is being port injected which generally has high octane number to bear the engine compression ratio in order to reduce knock [53]. It was reported that gasoline has high octane number-100 [57] and it can be used as low reactive fuel. However, it can also be utilised as high reactive fuel with the use of cetane enhancer (Di Tertiary Butyl Peroxide or Ethyl Hexyl Nitrate) [58-60]. The experiment results were reported with the use of normal gasoline (port injection) and gasoline doped with $0.75 \%, 1.75 \%$ and $3.5 \%$ Di Tertiary Butyl Peroxide (DTBP) by volume (direct injection). It was reported that $2 \%$ addition of DTBP to the gasoline provided much influence on ignition delay compared with the addition of 2-EHN (2-ethylhexyl nitrate) [29]. Test results were also reported with gasoline (port injected) and diesel (direct injected) with RCCI. It was stated that the injection pressure was reduced about 400 bar due to the high volatility of gasoline. A high gross indicated thermal efficiency of 57\% was reported using the single fuel strategy. However, no major changes in NOx and PM emissions were reported when compared with diesel/gasoline RCCI [61].

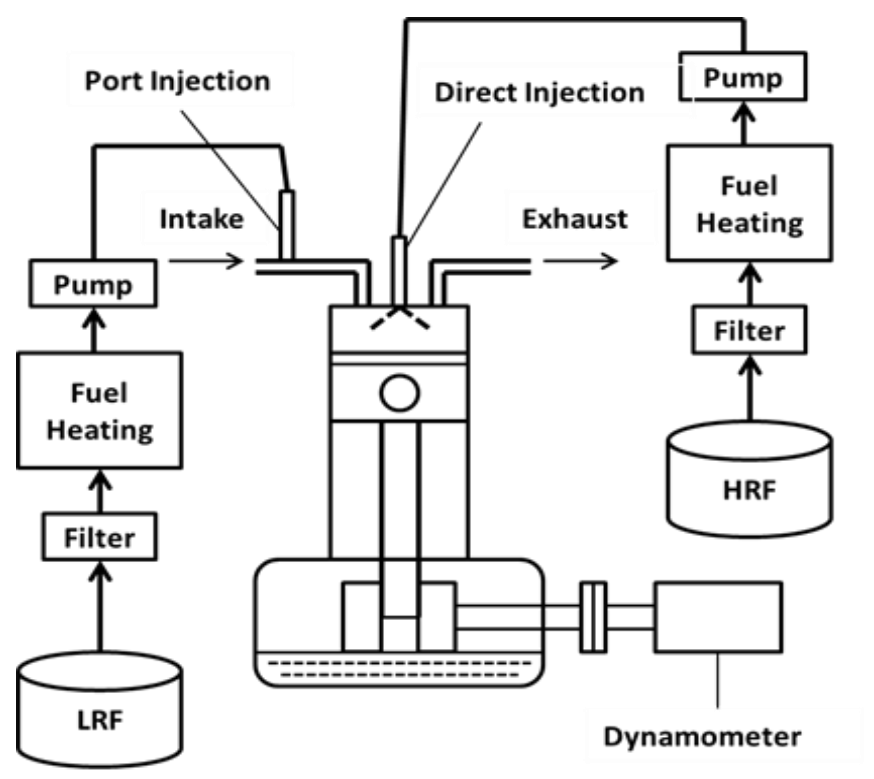

Figure 5. Experimental setup for RCCI with a direct and a port Injection [10]. 


\section{RCCI with a Port and a Direct Injection (Dual Fuel)}

RCCI of this type is similar to the dual fuel engine which uses two different fuels to create different reactivities with dual injectors to control combustion phasing, magnitude and duration. It has a port injector for low reactive fuel (LRF) and a direct injector for high reactive fuel (HRF) [14, 51, 56, 62-66]. Figure 5 shows the experimental setup for RCCI with port and direct injection (Dual fuel). Mixture formation is initiated by a wellmixed charge of air, low reactive fuel (injected in the intake port) and recirculated gas. The high reactive fuel is injected directly into the cylinder in one or two stages. The combustion in RCCI generally starts with premixed HRF-air and followed by a mixture of LRF and air as shown in Figure 6.
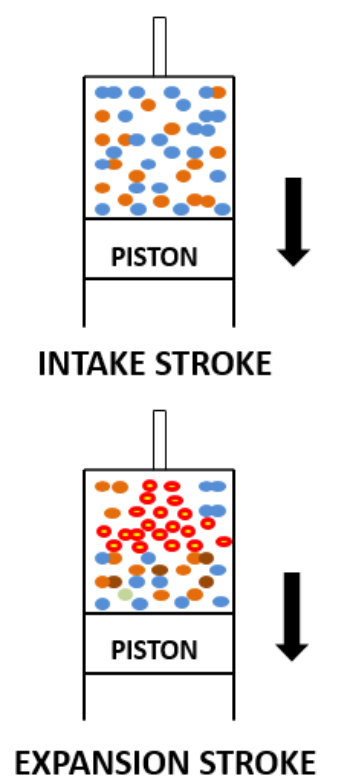
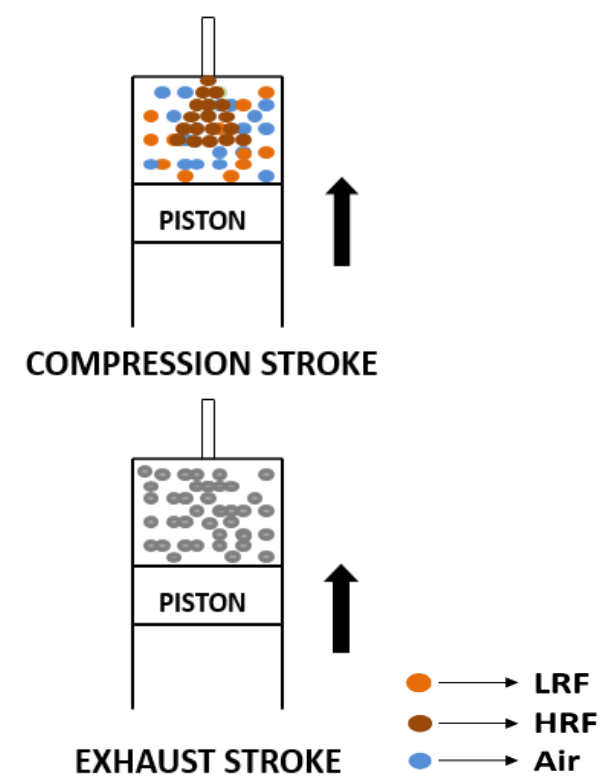

Figure 6. RCCI combustion process.

\section{Gasoline/diesel}

Diesel (HRF) and gasoline (LRF) are the fuels generally used since they are commercially available and they have a good difference in their self-ignition temperatures. Gasoline has a high octane number (98) and Diesel has a high cetane number $(52)[14,67]$. Fuels with high octane number can bear high compression ratios [68]. Fuels with high cetane number has low self-ignition temperatures and produce high rate of heat release [69]. Combustion of gasoline and diesel mixture generally takes place in stages [14], i.e. pre-mixed diesel combustion followed by low reactive gasoline combustion. HRF/LRF ratio contributes more in controlling the ignition delay and thereby combustion. If that ratio increases, the ignition delay decreases and vice versa $[14,56]$.

Table 5 shows the variation of heat release and NOx with respect to different fuel proportions (HRF/LRF). The peak heat release rate was reported to be increased by decreasing the HRF/LRF ratio until 50\% [14]. The maximum value of heat release rate occurred at a HRF/LRF ratio of $50 \%$. Further decrease in HRF/LRF ratio leads to the decrease in peak heat release rate due to high ignition delay that results in increasing unburnt hydro carbon emissions ( $5 \mathrm{~g} / \mathrm{kWh}$ ). NOx emission was reported to be high $(1 \mathrm{~g} / \mathrm{kWh})$ for diesel/ gasoline ratio of $25 \%$, since the peak heat release took place for a 
longer duration when compared to diesel/gasoline $50 \%(0.8 \mathrm{~g} / \mathrm{kWh})$, where the peak heat release took place in less duration.

Table 5. Variation of NOx and heat release rate with diesel/gasoline ratio [10].

\begin{tabular}{ccc}
\hline $\begin{array}{c}\text { Diesel/ Gasoline } \\
\text { Proportion } \\
\%\end{array}$ & $\begin{array}{c}\text { Peak rate of } \\
\text { Heat Release } \\
(\mathrm{J} / \mathrm{CAD})\end{array}$ & $\begin{array}{c}\text { NOx } \\
\text { emission } \\
(\mathrm{g} / \mathrm{kWh})\end{array}$ \\
\hline 100 & 300 & 0.9 \\
75 & 420 & 0.8 \\
50 & 520 & 0.8 \\
25 & 280 & 1 \\
\hline
\end{tabular}

Other test results are discussed for the variation of NOx and heat release with respect to the start of injection (SOI) of diesel [14]. Table 6 shows the reported values of NOx, with the increased SOI of diesel at a constant engine speed of $1200 \mathrm{rpm}$ and constant fuel quantity of $70 \mathrm{mg} / \mathrm{cycle}$. The HRF/LRF ratio was kept constant as $25 \%$ and SOI was varied from $15^{\circ}$ to $30^{\circ}$ BTDC. The RoHR increased slightly and started reducing at $\mathrm{SOI}$ of $21^{\circ} \mathrm{BTDC}$. NOx emission was found to be low at SOI $15^{\circ} \mathrm{BTDC}$ and started increasing as the SOI was advanced. This is because the peak RoHR values for SOI $30^{\circ} \mathrm{BTDC}(250 \mathrm{~J} / \mathrm{CAD})$ took place for a longer duration when compared to peak RoHR values for SOI $18^{\circ}$ BTDC (280 J/CAD).

Table 6. Variation of NOx and RoHR values with diesel SOI [10].

\begin{tabular}{ccc}
\hline $\begin{array}{c}\text { Diesel SOI } \\
(\mathrm{BTDC})\end{array}$ & $\begin{array}{c}\text { RoHR } \\
(\mathrm{J} / \mathrm{CAD})\end{array}$ & $\begin{array}{c}\text { NOx } \\
(\mathrm{g} / \mathrm{kWh})\end{array}$ \\
\hline 30 & 250 & 1 \\
21 & 270 & 0.9 \\
18 & 280 & 0.8 \\
15 & 260 & 0.7 \\
\hline
\end{tabular}

\section{Ethanol and Gasoline/n-heptane}

An experimental test was reported for Gasoline/n-Heptane and ethanol/n-Heptane combinations for a direct injected single cylinder Diesel engine [56]. In this study, ethanol and gasoline were used as LRF and n-heptane as HRF. The parameters such as peak pressure, heat release rate and maximum temperature rise with respect to premixed ratio were reported. Pre-mixed ratio is defined as the ratio of quantity of LRF to the combined quantity of LRF and HRF [56]. Test results in Table 7 were reported for constant heat addition $(\mathrm{Q}=1.05 \mathrm{~kJ} / \mathrm{cycle})$ and constant $\mathrm{SOI}$ of $\mathrm{n}$-heptane at $25^{\circ} \mathrm{BTDC}$. When the premixed ratio was increased, the quantity of LRF fuel was increased and hence the peak RoHR and peak pressure values were increased [Table 7]. The reason is, more premixed LRF fuel gets mixed with n-heptane during compression when the LRF proportion was increased. This resulted in the rapid combustion of premixed LRF and nheptane, leading to peak RoHR and peak pressure. This happened till the premixed ratio increased to 0.67. Further increase in premixed ratio led to the decrease in peak RoHR and peak pressure due to high proportion of LRF which caused high evaporation of LRF, leading to the decrease in the in cylinder temperature. 
Table 7. Variation of NOx, thermal efficiency, peak RoHR and peak cylinder pressure with premixed ratio [53].

\begin{tabular}{ccccc}
\hline $\begin{array}{c}\text { Pre mixed } \\
\text { Ratio }\end{array}$ & $\begin{array}{c}\text { Peak Heat } \\
\text { Release } \\
\text { Rate } \\
(\mathrm{J} / \mathrm{CA})\end{array}$ & $\begin{array}{c}\text { NOx } \\
(\mathrm{ppm})\end{array}$ & $\begin{array}{c}\text { Max } \\
\text { Cylinder } \\
\text { Pressure } \\
(\text { bar })\end{array}$ & $\begin{array}{c}\text { Indicated } \\
\text { Thermal } \\
\text { efficiency } \\
\%\end{array}$ \\
\hline \multicolumn{5}{c}{ Gasoline/n-heptane } \\
0.67 & 57 & 920 & 87 & 45 \\
0.57 & 48.5 & 620 & 81 & 46 \\
0.47 & 37.5 & 420 & 75 & 45 \\
\hline \multicolumn{5}{c}{ Ethanol/n-heptane } \\
0.67 & 62 & 380 & 80 & 43 \\
0.57 & 56 & 280 & 78 & 43.6 \\
0.47 & 45 & 120 & 70 & 42.6 \\
\hline
\end{tabular}

It was stated that NOx emission increased simultaneously when the premixed ratio was increased until 0.67 and decreased with the further increase in premixed ratio [Table 7]. Increase in premixed ratio resulted in an increased quantity of LRF. Combustion occurs in the premixed combustion zone which increases the in-cylinder temperature, resulting in high NOx emissions. Further increase in premixed ratio leads to a low quantity of $n$-Heptane inside the cylinder. This reduces the local combustion temperature which results in decreased NOx emissions. Thermal efficiency was reported to be increased when the pre-mixed ratio was increased from 0.47 to 0.57 . It was then decreased on further increase of premixed ratio to 0.67 [Table 7]. The cylinder temperature increases with the premixed ratio, resulting in complete combustion. Further increase causes a combustion phasing advance, which induces the negative work on piston.

\section{Natural gas/diesel}

Natural gas has a very high self-ignition temperature $\left(\right.$ SIT $\left.580^{\circ} \mathrm{C}\right)$ and octane number (120). Diesel (SIT $223^{\circ} \mathrm{C}$ ) can be combined with natural gas for RCCI operation [70]]. A test was performed in 2.44L Diesel Engine with a compression ratio of 16:1. Natural Gas (LRF) was taken in two mixtures Gas A and Gas B. Gas A is pure Methane and Gas B had Methane 78.2\%, Ethane 2.31\%, Propane 0.25\%, N2 $18.89 \%$ and CO2 $0.28 \%$. Diesel was taken as HRF fuel [63]. The combustion parameters are shown in Table 8. The results were reported for constant HRF/LRF 25\% and constant SOI 1 and SOI 2 at $80^{\circ}$ and $40^{\circ}$ BTDC respectively. The fraction of diesel injected at SOI 1 and SOI 2 was $50 \%$ (constant). When the intake temperature was increased, the reaction rate increased which in turn increased the NOx. Higher intake temperature leads to advancing the combustion phasing and low ignition delay, which is the main reason for high NOx emissions. The volumetric efficiency was observed to be decreased with the increase in intake temperature due to the decrease in intake charge density. Gas A showed higher pressure and temperature rise when compared to Gas B, since Gas A is pure methane whereas Gas B is a mixture of methane, ethane, propane, N2 and CO2. The high proportion of $\mathrm{N}_{2}$ increased the specific heat capacity of Gas $\mathrm{B}$, which caused the lower pressure and temperature rise. 
Table 8. Variation of RoHR, peak pressure and peak temperature with intake temperature [63].

\begin{tabular}{ccccccc}
\hline $\begin{array}{c}\text { Intake } \\
\text { Temperature }\left({ }^{\circ} \mathrm{C}\right)\end{array}$ & \multicolumn{2}{c}{$\begin{array}{c}\text { RoHR } \\
(\mathrm{J} / \mathrm{deg})\end{array}$} & \multicolumn{2}{c}{$\begin{array}{c}\text { Peak } \\
\text { Pressure }(\mathrm{MPa})\end{array}$} & \multicolumn{2}{c}{$\begin{array}{c}\text { Peak } \\
\text { Temperature }(\mathrm{K})\end{array}$} \\
\hline & $\mathrm{A}$ & $\mathrm{B}$ & $\mathrm{A}$ & $\mathrm{B}$ & $\mathrm{A}$ & $\mathrm{B}$ \\
60 & 3000 & 2625 & 10 & 8.75 & 1700 & 1100 \\
100 & 4500 & 4125 & 15 & 13.75 & 2000 & 1800 \\
120 & 4350 & 3750 & 14 & 12.5 & 2100 & 1875 \\
\hline
\end{tabular}

Table 9 shows the variation of NOx and CA50 values with respect to the intake temperature. As the intake temperature increases, the CA50 value gets advanced for both Gas A and Gas B. The NOx emission using Gas A increases with the intake temperature at a very high rate when compared to Gas B. Since Gas A is pure methane, its specific heat capacity (SPC) is less and it needs very little heat to attain its self-ignition temperature, thus increasing the in cylinder temperature. Gas B being a mixture of methane, ethane, propane, $\mathrm{N} 2$ and $\mathrm{CO} 2$ has a very high specific heat capacity and needs more heat to attain its self -ignition temperature, thus reducing the in-cylinder temperature. This resulted in very little NOx emission with Gas B when compared to Gas A.

Table 9. Variation of CA 50 and NOx with intake temperature [63].

\begin{tabular}{ccccc}
\hline $\begin{array}{c}\text { Intake } \\
\text { Temperature }{ }^{\circ} \mathrm{C}\end{array}$ & \multicolumn{2}{c}{$\begin{array}{c}\text { CA50 } \\
(\text { ATDC) }\end{array}$} & \multicolumn{2}{c}{$\begin{array}{c}\text { NOx } \\
(\mathrm{g} / \mathrm{kWh})\end{array}$} \\
\hline & $\mathrm{A}$ & $\mathrm{B}$ & $\mathrm{A}$ & $\mathrm{B}$ \\
60 & 10 & 10.5 & $<0.2$ & $<0.2$ \\
100 & -4 & -3 & 0.5 & $<0.2$ \\
120 & -7 & -6 & 1.4 & 0.1 \\
\hline
\end{tabular}

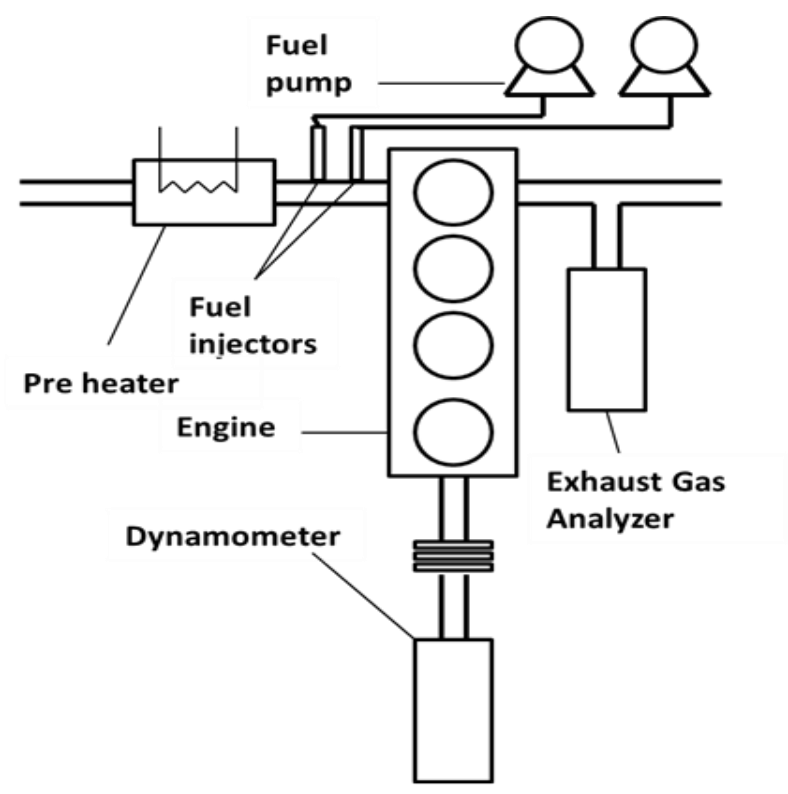

Figure 7. Experimental setup for RCCI with dual port injection [70]. 


\section{RCCI with Dual Port Injection}

In this method, both the LRF and HRF fuels were injected at the intake port. The fuel sprays were targeted on the back side of the intake valve to improve the vaporisation. This method is also referred to as dual fuel HCCI [71-73]. This system uses the main fuel with high octane number (LRF) and secondary fuel with low octane number (HRF) [73]. When both fuels are injected in the intake port, the air-fuel mixture is homogeneous since the mixture remains the same and uniform throughout the cycle. A typical experimental setup is shown in Figure 7. Since the fuels get port injected, a pre heater setup is added to overcome the challenges in port injection such as poor atomisation, poor vaporisation and cylinder wall impingement.

Table 10 shows the fuel combinations that work out better for this method. nHeptane (HRF) has a flash point of $25^{\circ} \mathrm{C}$ and it gets vaporised easily when it is injected in the intake port as compared to Diesel (flash point is about $50-95^{\circ} \mathrm{C}$ ) [6]. Diesel can also be used as a high reactive fuel. At low loads, diesel vaporisation becomes a difficult task due to low in-cylinder and manifold temperatures. An additional vaporiser unit can help to solve this problem [74].

Table 10. Fuel combinations for RCCI with dual port injection.

\begin{tabular}{cccc}
\hline LRF & HRF & LRF & HRF \\
\hline Iso-Octane & n-Heptane & 280 & 223 \\
Natural Gas & n-Heptane & 580 & 223 \\
Methanol & n-Heptane & 470 & 223 \\
\hline
\end{tabular}

Table 11. Variation of CA50 with different HRF/LRF ratio [70].

\begin{tabular}{ccc}
\hline Injected Energy & HRF/LRF Ratio & CA50 (ATDC) \\
\hline \multirow{3}{*}{ 700J } & 0 & 10 \\
& 0.2 & 7 \\
& 0.4 & 2 \\
& 0.5 & 0 \\
800J & 0.6 & -4 \\
\hline & 0 & 9 \\
& 0.2 & 6 \\
& 0.3 & 4 \\
& 0.4 & 2 \\
& 0.5 & -1 \\
\hline
\end{tabular}

\section{Methanol/n-heptane}

Methanol (SIT-470 $\left.{ }^{\circ} \mathrm{C}\right)$ and n-heptane $\left(\mathrm{SIT}-223^{\circ} \mathrm{C}\right)$ have a good difference in their selfignition temperature. Generally, methanol can be taken as LRF and n-heptane can be taken as HRF. n-Heptane has low self-ignition temperature than methanol, which helps to advance combustion i.e. CA50 values with increasing HRF/LRF ratio [73]. Table 11 shows the results from literature [73] at a constant speed of $1200 \mathrm{rpm}$ and constant heat addition of $700 \mathrm{~J} /$ cycle and $800 \mathrm{~J} /$ cycle. CA50 values were observed to be advanced with the increase in HRF/LRF ratio. When the proportion of n-Heptane (HRF) increases, the charge becomes highly reactive. This makes the charge attain its self-ignition temperature at the earlier crank angles. Table 12 shows the variation of rate of pressure 
rise (RoPR) with different HRF/LRF ratios from the literature [73]. RoPR increases with the increase in HRF/LRF ratio due to the advanced combustion.

Table 12. Variation of RoPR with HRF/LRF ratio [70].

\begin{tabular}{ccc}
\hline Injected Energy & HRF/LRF Ratio & ROPR (bar/CAD) \\
\hline \multirow{3}{*}{ 700J } & 0 & 1 \\
& 0.2 & 1 \\
& 0.4 & 6 \\
& 0.5 & 9 \\
800J & 0.6 & 14 \\
\hline & 0 & 1 \\
& 0.2 & 2 \\
& 0.3 & 5 \\
& 0.4 & 8 \\
\hline
\end{tabular}

\section{Iso-Octane/n-heptane}

Iso-Octane $\left(\mathrm{SIT}-280^{\circ} \mathrm{C}\right)$ and $\mathrm{n}$-heptane $\left(\mathrm{SIT}-223^{\circ} \mathrm{C}\right)$ were also reported in combustion control in RCCI mode with dual injection in the intake port. Table 13 shows the combustion parameter (CA 50) at a constant intake pressure of 1.5 bar and constant intake temperature of $75^{\circ} \mathrm{C}$ and constant speed of $1200 \mathrm{rpm}$.

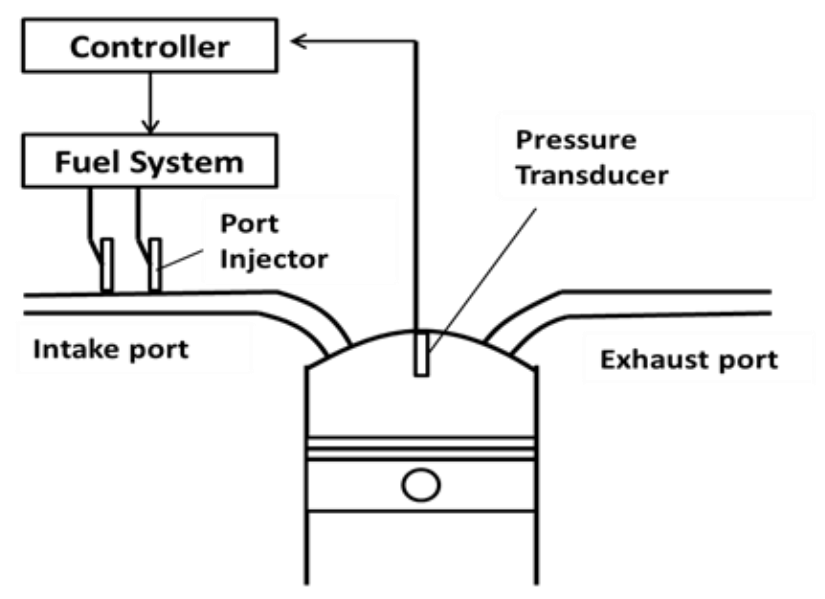

Figure 8. Experimental setup for Iso-Octane/N-heptane combination [12]

Iso-Octane was taken as LRF and n-Heptane was taken as HRF. Increasing the Iso-Octane proportion extended the range of load of operation to an IMEP of 7.2 bar. Variation of Indicated Mean Effective Pressure with respect to Equivalence Ratio and fuel proportions shows that maximum work was obtained at higher equivalence ratios and increased proportion of LRF [72]]. The calorific value of Iso-octane is high when compared with n-Heptane. Increasing the proportion of LRF increases the energy density of mixture which makes the engine delivers high IMEP. Table 13 shows the variation of CA50 with respect to equivalence ratio and fuel proportions at $1200 \mathrm{rpm}$ [72]. 
Table 13. Variation of CA50 with HRF/LRF and Equivalence ratios [69].

\begin{tabular}{ccc}
\hline HRF/LRF & Equivalence Ratio & CA50 (ATDC) \\
\hline 0.6 & 0.15 & 2 \\
& 0.25 & -6 \\
& 0.3 & -9 \\
\hline 0.4 & 0.15 & Misfire \\
& 0.25 & -1 \\
& 0.3 & -5 \\
\hline 0.2 & 0.15 & Misfire \\
& 0.25 & Misfire \\
& 0.3 & 5 \\
\hline
\end{tabular}

The combustion phasing gets advanced with the increase in equivalence ratios and HRF/LRF proportions. The charge becomes highly reactive with the increasing HRF/LRF ratio which attains the self-ignition temperature at earlier crank angles. Generally, misfire occurs when the air-fuel mixture does not attain its self-ignition temperature during compression. Table 13 shows that misfire took place at three cases where the equivalence ratio and HRF/LRF proportion were less. Low equivalence ratio (0.15) and low HRF/LRF proportion led to low fuel proportion and reactivity for the start of combustion [71]. Table 14 shows that the IMEP values increases as the LRF proportion increases. It was reported that when using n-heptane and Iso-octane mixtures, the load range cannot be extended to low loads and separate process like intake charge heating can help to overcome this problem. NOx emissions reported in all cases were found to be less than $8 \mathrm{ppm}$ [71]. The summary of all the combustion control methods discussed previously is given in table 15 as key points.

Table 14. Variation of IMEP with LRF/HRF ratio at different speeds [12].

\begin{tabular}{ccc}
\hline Speed (rpm) & Fuel proportion (HRF/LRF) & IMEP (bar) \\
\hline 1200 & 0.4 & 5.2 \\
& 0.6 & 5.4 \\
& 0.8 & 6 \\
\hline 1500 & 0.4 & 5.5 \\
& 0.6 & 5.6 \\
1800 & 0.8 & 6.6 \\
\hline & 0.4 & 5.5 \\
& 0.6 & 5.7 \\
& 0.8 & 7.2 \\
\hline
\end{tabular}

\section{Factors Influencing the Combustion Control}

A consolidated discussion on the factors influencing combustion control using fuel reactivities is given below. This makes a garland of this review.

\section{Fuel Properties}

Fuel properties such as cetane number, octane number and self-ignition temperature highly influence the RCCI operation. RCCI and HCCI focus on low temperature combustion (LTC) to reduce NOx emissions $[44,75]$. LTC is limited to short ignition 
delays. It has been reported that Wide Distillation Fuel (WDF) ignition delays are better than commercial fuels [75]. This is done by the direct blending of high octane and high cetane number to enhance the atomization and evaporation of fuel.

Table 15. Summary on different combustion control methods.

\begin{tabular}{|c|c|c|}
\hline Method & Variable parameter & Key points \\
\hline $\begin{array}{l}\text { Varying the } \\
\text { compression ratio }\end{array}$ & Compression ratio & $\begin{array}{l}\text { To avoid knocking at high loads, the } \\
\text { compression ratio has to be decreased to } \\
\text { obtain longer ignition delays } \\
\text { To reduce misfire at part loads, the } \\
\text { compression ratio has to be increased to } \\
\text { obtain short ignition delays for better } \\
\text { combustion. }\end{array}$ \\
\hline $\begin{array}{l}\text { Exhaust gas } \\
\text { recirculation }\end{array}$ & $\begin{array}{l}\text { Specific heat } \\
\text { capacity of intake } \\
\text { charge }\end{array}$ & $\begin{array}{l}\text { EGR helps to obtain a better retard in } \\
\text { combustion phasing. } \\
\text { Increase in EGR proportion increases the } \\
\text { thermal efficiency and IMEP, favouring } \\
\text { the high load operation of HCCI mode at a } \\
\text { constant speed. }\end{array}$ \\
\hline $\begin{array}{l}\text { Fast thermal } \\
\text { management }\end{array}$ & $\begin{array}{l}\text { Intake charge } \\
\text { temperature }\end{array}$ & $\begin{array}{l}\text { By increasing the intake charge } \\
\text { temperature, combustion phasing (CA50) } \\
\text { can be advanced. } \\
\text { This advanced combustion phasing will } \\
\text { favour part load operations. }\end{array}$ \\
\hline $\begin{array}{l}\text { Supercharging or } \\
\text { turbo charging }\end{array}$ & $\begin{array}{l}\text { Intake charge } \\
\text { pressure }\end{array}$ & $\begin{array}{l}\text { Increase in boost pressure can improve the } \\
\text { operating temperature of HCCI. } \\
\text { Turbo charging in HCCI mode favours to } \\
\text { increase the high load operating range. }\end{array}$ \\
\hline \multirow[t]{6}{*}{ RCCI } & Fuel proportion & $\begin{array}{l}\text { RCCI with a port and direct injection } \\
\text { (Single fuel) }\end{array}$ \\
\hline & & $\begin{array}{l}\text { Gasoline was used as LRF and gasoline } \\
\text { doped with DTBP or 2-EHN was used as } \\
\text { HRF } \\
\text { Use of DTBP showed better influence on } \\
\text { ignition delay }\end{array}$ \\
\hline & & $\begin{array}{l}\text { RCCI with a port and direct injection } \\
\text { (Dual fuel) }\end{array}$ \\
\hline & & $\begin{array}{l}\text { Increasing the LRF proportion decreases } \\
\text { the NOx emissions. } \\
\text { Ignition delay increases when the } \\
\text { HRF/LRF ratio decreases and vice versa. } \\
\text { Excess LRF proportion results in high } \\
\text { hydro carbon emissions. }\end{array}$ \\
\hline & & RCCI with dual port injection \\
\hline & & $\begin{array}{l}\text { Increasing the HRF/LRF proportion } \\
\text { advances the combustion phasing } \\
\text { A better reduction in NOx emission was } \\
\text { observed for any proportion because the } \\
\text { charge remains homogeneous. }\end{array}$ \\
\hline
\end{tabular}


Fuels are distinguished as low reactive and high reactive based on their cetane numbers $(\mathrm{CN})$. It was reported that fuels with $\mathrm{CN}<30$ are said to be below reactive and fuels with $\mathrm{CN}>60$ are said to be high reactive [76]. Fuels with high cetane number has straight chain alkanes, straight chain ethers and long straight chain esters, making it highly reactive [57]. Hence, it has been suggested to use high cetane number fuel as HRF and low cetane number fuel as LRF.

\section{Intake Air Temperature}

Intake Air Temperature plays a vital role in combustion control. Increase in the intake air temperature increases the in cylinder gas temperature at the end of compression, resulting in an accelerated chemical reaction. Thus, combustion gets advanced with the increase in intake air temperature [76]. It was reported that every $10^{\circ} \mathrm{C}$ rise in intake temperature increases the reaction rate by 2-4 times when other parameters remain constant [77]. Rich mixture ignition is favourable at low air temperature and lean mixture ignition is favourable at high air temperature. Coefficient of variation of max pressure rise increases with the increase in intake air temperature and increasingly richer mixture. Hence, high intake air temperature along with a rich mixture results in knocking [78]. Generally, a low cetane value fuel requires intake charge heating, favouring the auto ignition. Though increase in intake charge temperature favours ignition advance, it results in low volumetric and thermal efficiency. This is because increase in intake charge temperature reduces the density of the charge, resulting in low volume of charge entering the cylinder [79]. Also, large advancement in combustion phasing causes negative work on the piston, resulting in low thermal efficiency [33].

\section{Intake Pressure}

Output power in SI and CI engines can be improved by intake pressure boosting. Effects of intake pressure on heat release rate, combustion efficiency, mechanical efficiency, coefficient of variation of IMEP and emissions have been reported in the literature [80], [81]. It was reported that combustion duration decreases with the increasing intake boost pressure. The progress of combustion is reduced if the combustion starts after TDC, since the volume increases during expansion stroke. It was reported that the mean effective pressure increases with the increase in boost pressure, but decreases with speed. Mean effective pressure is defined as the ratio of work done to stroke volume. Work done decreases with the increase in speed, since mechanical friction increases with the increase in speed, resulting in less work done.

Combustion efficiency was reported to have an inverse relationship when compared with mechanical and thermal efficiency, since combustion efficiency increases with speed. Mechanical and thermal efficiencies increase with the increase in intake pressure but decrease with speed. When the speed increases, the friction increases, which causes the mechanical efficiency to decrease. This reduces the work done, thus resulting in a decreased thermal efficiency since thermal efficiency is the ratio of work done to heat input [80]. It was reported that at low loads, when the intake pressure increases, the coefficient of variation (CoV) of IMEP decreases. Meanwhile, on further increase in intake pressure, the COV of IMEP increases. When the intake pressure increases, the amount of air in the charge increases and the charge becomes lean. This lean charge will lead to an unstable combustion, resulting in an increased CoV of IMEP [82]. 


\section{Fuel Proportions}

Fuel proportion has a great influence on in-cylinder pressure. Peak pressure values were obtained as the LRF (Gasoline) proportion increased, but the use of $100 \%$ gasoline resulted in misfire since it has a high octane number. The time interval between CA5 and CA90 is known as the combustion duration. This duration was shortened with the increase in Gasoline proportion, since faster depletion of homogeneous mixture of air and gasoline took place [83]. As soon as the combustion was initiated, its evolution was determined by low reactivity fuel characteristics and high reactive fuel stratification. Increase in low reactivity with high reactive fuel stratification led to less combustion duration and high rate of heat release [13]. In the case of combustion phasing control using fuel proportions, CA50 remains the index for control. Fuel proportions can also avoid high rate of pressure rise and misfire conditions. CA50 reference values are generally used to decide the fuel proportions. Combustion phasing gets advanced as the proportion of HRF fuel increases [14].

\section{Injection Timing}

Injection timing has greater influence on RCCI using a port and direct injection when compared to dual port injection. It was reported that delay in direct injection leads to a two stage heat release since the premixed combustion takes place initially, followed by the diffusion combustion whereas advanced direct injection leads to a single stage heat release [84]. It was reported that by keeping Start of Ignition (SOI) constant around $-30^{\circ}$ ATDC and increasing the LRF proportion, it improves the ignition delay, whereas keeping SOI around -10 ATDC and increasing the LRF proportion has no significant effects on delayed ignition. It was reported that NOx emissions gets reduced at advanced SOI $\left(35^{\circ} \mathrm{BTDC}\right)$ when compared with conventional SOI ( $\left.7^{\circ} \mathrm{BTDC}\right)$. Early SOI increases the ignition delay, which results in more homogeneous mixture. This avoids the high temperature regions during combustion, resulting in very little NOx emission $(<2 \mathrm{~g} / \mathrm{kWh})$ [83].

\section{CONCLUSIONS}

Emission norms are becoming stringent day by day. The permitted NOx emission for Euro VI norms is nearly zero $(<0.4 \mathrm{~g} / \mathrm{kWh})$. Diesel engines at present are able to meet Euro IV norms $(\mathrm{NOx}<3 \mathrm{~g} / \mathrm{kWh})$. It is a great challenge for a directed injected diesel engine to avoid peak heat release rate which facilitates NOx formation. HCCI and RCCI technology can reduce those peak heat release rates and meet stringent NOx emissions. Literatures clearly indicate the possibility of achieving less NOx emissions at high thermal efficiencies. The challenges like lack in combustion control and operating range extension can be addressed by implementing an effective control on parameters like intake pressure, intake temperature, fuel proportions, injection timing and specific heat capacities of intake charge. It can be concluded that reactivity based control (RCCI) has good flexibility in optimizing combustion phasing and load range to a greater extent when compared to turbo charging, exhaust gas recirculation, fast thermal management and variable compression ratio. Only few literatures were reported in the case of RCCI with dual port injection. Further studies on this particular method can improve HCCI engine performance with very low NOx emissions. On the whole, this article can be a knowledge base for further investigations in HCCI and RCCI technology to meet stringent future emission norms by implementing fuel reactivity based combustion control. 


\section{ACKNOWLEDGEMENTS}

We would like to thank our VIT University and School of Mechanical and Building Sciences (SMBS) for providing continuous support, source and encouragement for our research work and publications.

\section{REFERENCES}

[1] Hasan MM, Rahman MM. Homogeneous charge compression ignition combustion: Advantages over compression ignition combustion, challenges and solutions. Renewable and Sustainable Energy Reviews. 2016;57:282-91.

[2] A. Aziz AR. Investigation of Auto-Ignition of Octane-Cng Mixture in Hcci Engine. International Journal of Automotive and Mechanical Engineering. 2015;11:2235-42.

[3] Mohanamurugan S, Sendilvelan S. Emission and Combustion Characteristics of Different Fuel In A HCCI Engine. International Journal of Automotive and Mechanical Engineering. 2011;3:279-92.

[4] Hairuddin AA, Wandel AP, Yusaf T. An introduction to a homogeneous charge compression ignition engine. Journal of Mechanical Engineering and Sciences. 2014;7:1042-52.

[5] Hasan MM, Rahman MM, Kadirgama K. A Review on Homogeneous Charge Compression Ignition Engine Performance Using Biodiesel-Diesel Blend as a Fuel. International Journal of Automotive and Mechanical Engineering. 2015;11:2199-211.

[6] Xingcai L, Yuchun H, Linlin Z, Zhen H. Experimental study on the auto-ignition and combustion characteristics in the homogeneous charge compression ignition (HCCI) combustion operation with ethanol/n-heptane blend fuels by port injection. Fuel 2006;85:2622-31.

[7] Janakiraman VM, Nguyen X, Assanis. D. An ELM based predictive control method for HCCI engines. Engineering Applications of Artificial Intelligence. 2016;48:106-18.

[8] Supeni EE, Yusaf TF, Wandel AP, Buttsworth DR, Noor. MM. Experimental and modeling investigation of the performance characteristics on diesel HCCI with hydrogen additive- a review. . National Conference in Mechanical Engineering Research and Postgraduate Studies. 2010:580-96.

[9] Lee K, Cho S, Kim N, Min. K. A study on combustion control and operating range expansion of gasoline HCCI. Energy. 2015;91:1038-48.

[10] Haraldsson G, Tunestål P, Johansson. B. HCCI Combustion Phasing in a Multi Cylinder engine using Variable Compression Ratio. SAE 2002-01-2858. 2002:12.

[11] Jung D, Iida. N. Closed-loop control of HCCI combustion for DME using external EGR and rebreathed EGR to reduce pressure-rise rate with combustion-phasing retard. Applied Energy. 2015;138:315-30.

[12] Haraldsson G, Tunestål P, Johansson B. HCCI Closed-Loop Combustion Control Using Fast Thermal Management. . SAE 2004-01-0943. 2004.

[13] Benajes J, Molina S, García A, Monsalve-Serrano J. Effects of low reactivity fuel characteristics and blending ratio on low load RCCI (reactivity controlled compression ignition) performance and emissions in a heavy-duty diesel engine. Energy. 2015;90:1261-71. 
[14] Benaje J, Molina S, García A, Belarte E, Vanvolsem M. An investigation on RCCI combustion in a heavy duty diesel engine using in-cylinder blending of diesel and gasoline fuels. Applied Thermal Engineering. 2014;63:66-76.

[15] Aldawood A, Mosbach S, Kraft M. HCCI Combustion Control Using Dual-Fuel Approach: Experimental and Modeling Investigations. . SAE Technical Paper No 2012-01-1117. 2012.

[16] Yao M, Zheng Z, Liu. H. Progress and recent trends in homogeneous charge compression ignition (HCCI) engines. Progress in Energy and Combustion Science. 2009;35 398-437.

[17] Hasan MM, Rahman MM. Homogeneous charge compression ignition combustion: Advantages over compression ignition combustion, challenges and solutions. Renewable and Sustainable Energy Reviews 2016;57 282-91.

[18] Garcia MT, Aguilar FJJ-E, Lencero TS. Experimental study of the performances of a modified diesel engine operating in homogeneous charge compression ignition (HCCI) combustion mode versus the original diesel combustion mode. Energy. 2009;34:159-71.

[19] Lu X, Han D, Huang Z. Fuel design and management for the control of advanced compression-ignition combustion modes. . Progress in Energy and Combustion Science. 2011;37 741-83.

[20] Killingsworth NJ, Aceves SM, Flowers DL, Espinosa-Loza F, Krstic M. HCCI Engine Combustion-Timing Control: Optimizing Gains and Fuel Consumption via Extremum Seeking. . IEEE Transactions on Control Systems Technology 2009;17.

[21] Polat. S. An experimental study on combustion, engine performance and exhaust emissions in a HCCI engine fuelled with diethyl ether-ethanol fuel blends. Fuel Processing Technology. 2016;143:140-50.

[22] Gan S, Ng HK, Pang. KM. Homogeneous Charge Compression Ignition (HCCI) combustion: Implementation and effects on pollutants in direct injection diesel engines. Applied Energy. 2011;88:559-67.

[23] Saxena S, Schneider S, Aceves S, Dibble. R. Wet ethanol in HCCI engines with exhaust heat recovery to improve the energy balance of ethanol fuels. Applied Energy. 2012;98:448-57.

[24] Ahn K, Whitefoot J, Babajimopoulos A, Ortiz-Soto E, Papalambros. PY. Homogeneous charge compression ignition technology implemented in a hybrid electric vehicle: System optimal design and benefit analysis for a powersplit architecture. Journal of Automobile Engineering.2013;227:87-98.

[25] Kumar P, Rehman A. Homogeneous Charge Compression Ignition (HCCI) Combustion Engine- A Review. Journal of Mechanical and Civil Engineering. 2014;11:47-67.

[26] Su H, Mosbach S, Kraft. M. Two-stage Fuel Direct Injection in a Diesel Fuelled HCCI Engine. SAE 2007-01-1880 2007.

[27] Chintala V, Subramanian. KA. Experimental investigation of hydrogen energy share improvement in a compression ignition engine using water injection and compression ratio reduction. Energy Conversion and Management. 2016;108:106-19.

[28] Hillion M, Chauvin J, PETIT. N. Open-loop Combustion Timing Control of a Spark-Ignited Engine. Proceedings of the 47th IEEE Conference on Decision and Control. Cancun, Mexico.2008. 
[29] Tanaka S, Ayala F, Keck JC, Heywood. JB. Two-stage ignition in HCCI combustion and HCCI control by fuels and additives. Combustion and Flame 2003;132:219-39.

[30] Bora BJ, Saha. UK. Experimental evaluation of a rice bran biodiesel - biogas run dual fuel diesel engine at varying compression ratios. Renewable Energy. 2016;87:782-90.

[31] Bora BJ, Saha. UK. Optimisation of injection timing and compression ratio of a raw biogas powered dual fuel diesel engine. Applied Thermal Engineering. 2016;92:111-21.

[32] Lei Shi KD, Yi Cui SQ, Hu. W. Study on knocking combustion in a diesel HCCI engine with fuel injection in negative valve overlap. Fuel. 2013;106:478-83.

[33] Bendu H, Murugan. S. Homogeneous charge compression ignition (HCCI) combustion: Mixture preparation and control strategies in diesel engines. . Renewable and Sustainable Energy Reviews. 2014;38:732-46.

[34] Tangoz S, Akansu SO, Kahraman N, Malkoc. Y. Effects of compression ratio on performance and emissions of a modified diesel engine fueled by HCNG. International Journal of Hydrogen Energy. 2015;40:15374-80.

[35] Hariram V, Shangar. RV. Influence of compression ratio on combustion and performance characteristics of direct injection compression ignition engine. Alexandria Engineering Journal. 2015;54:807-14.

[36] d'Ambrosio S, Ferrari. A. Effects of exhaust gas recirculation in diesel engines featuring late PCCI type combustion strategies. Energy Conversion and Management. 2015;105:1269-80.

[37] Wei H, Zhu T, Shu G, Tan L, Wang. Y. Gasoline engine exhaust gas recirculation - A review. Applied Energy. 2012;99:534-44.

[38] Agarwal D, Singh SK, Agarwal. AK. Effect of Exhaust Gas Recirculation (EGR) on performance, emissions, deposits and durability of a constant speed compression ignition engine. Applied Energy. 2011;88:2900-7.

[39] Kozarac D, Vuilleumier D, Saxena S, Dibble. RW. Analysis of benefits of using internal exhaust gas recirculation in biogas-fueled HCCI engines. Energy Conversion and Management. 2014;87:1186-94.

[40] Olsson J-O, Tunestål P, Ulfvik J, Johansson B. The Effect of Cooled EGR on Emissions and Performance of a Turbocharged HCCI Engine. SAE 2003-01-0743 2003.

[41] Elkelawy M. Experimental Investigation of Intake Diesel Aerosol Fuel Homogeneous Charge Compression Ignition (HCCI) Engine Combustion and Emissions. Energy and Power Engineering. 2014;6:513-26.

[42] Zheng M, Reader GT, Hawley. JG. Diesel engine exhaust gas recirculation-a review on advanced and novel concepts. Energy Conversion and Management. 2004;45:883-900.

[43] Shi L, Cui Y, Deng K, Peng H, Chen. Y. Study of low emission homogeneous charge compression ignition (HCCI) engine using combined internal and external exhaust gas recirculation (EGR). Energy. 2006;31:2665-76.

[44] Saxena S, D.Bedoya. I. Fundamental phenomena affecting low temperature combustion and HCCI engines, high load limits and strategies for extending these limits. Progress in Energy and Combustion Science. 2013;39:457-88.

[45] Fu J, Liu J, Wang Y, Deng B, Yang Y, Feng R, et al. A comparative study on various turbocharging approaches based on IC engine exhaust gas energy recovery. Applied Energy. 2014;113:248-57. 
[46] Kusztelan A, Yao YF, Marchant DR, Y.Wang. A Review of Novel Turbocharger Concepts for Enhancements in Energy Efficiency. International Journal of Thermal \& Environmental Engineering. 2011;2:75-82.

[47] Muqeem M, Kumar. DM. Turbocharging of IC engine: a review. International Journal of Mechanical Engineering And Technology 2013;4:142-9.

[48] Muqeem. M. Turbocharging With Air Conditioner Assisted Intercooler. IOSR Journal of Mechanical and Civil Engineering. 2012;2:38-44.

[49] Lee T, Reitz RD. The effect of intake boost pressure on MK (Modulated Kinetics) combustion. JSME International Journal Series B Fluids and Thermal Engineering. 2003;46:451-9.

[50] Olsson J-O, Per Tunestål G, Haraldsson, Johansson. B. A turbo charged dual fuel HCCI engine. SAE 2001-01-1896. 2001.

[51] Li J, Yang WM, Ana H, Zhou DZ, Yu WB, Wang JX, et al. Numerical investigation on the effect of reactivity gradient in an RCCI engine fueled with gasoline and diesel. Energy Conversion and Management. 2015;92:342-52.

[52] Splitter DA, Hanson RM, Kokjohn SL, Reitz RD. Improving Engine Performance by Optimizing Fuel Reactivity with a Dual Fuel PCCI Strategy. Conference on Thermo- and Fluid Dynamic Processes in Diesel Engines. 2010. p. 1-18.

[53] Wang H, Zheng Z, Liu H, Yao M. Combustion mode design with high efficiency and low emissions controlled by mixtures stratification and fuel reactivity. Frontiers in Mechanical Engineering. 2015;1:1-12.

[54] Zhou DZ, Yang WM, An H, Li J. Application of CFD-chemical kinetics approach in detecting RCCI engine knocking fuelled with biodiesel/methanol. Applied Energy. 2015;145:255-64.

[55] Li J, Yang WM, Goh TN, An H, Maghbouli A. Study on RCCI (reactivity controlled compression ignition) engine by means of statistical experimental design. Energy. 2014;78:777-87.

[56] Qian Y, Wang X, Zhu L, Lu X. Experimental studies on combustion and emissions of RCCI (reactivity controlled compression ignition) with gasoline/nheptane and ethanol/n-heptane as fuels. Energy. 2015;88:584-94.

[57] Han WQ, Yao CD. Research on high cetane and high octane number fuels and the mechanism for their common oxidation and auto-ignition. Fuel. 2015;150:29-40.

[58] Splitter D, Reitz R, Hanson R. High efficiency, low emissions RCCI combustion by use of a fuel additive. SAE International. 2010;3:742-56.

[59] Starck L, Lecointe B, Forti L, Jeuland N. Impact of fuel characteristics on HCCI combustion: Performances and emissions. Fuel 2010;89:3069-77.

[60] Splitter DA, Reitz RD. Fuel reactivity effects on the efficiency and operational window of dual-fuel compression ignition engines. Fuel. 2014;118:163-75.

[61] Reitz RD, Duraisamy G. Review of high efficiency and clean reactivity controlled compression ignition (RCCI) combustion in internal combustion engines. Progress in Energy and Combustion Science. 2015;46:12-71.

[62] Li Y, Jia M, Liu Y, Xie M. Numerical study on the combustion and emission characteristics of a methanol/diesel reactivity controlled compression ignition (RCCI) engine. Applied Energy 2013;106:184-97.

[63] Kakaee A-H, Rahnama P, Paykani A. Influence of fuel composition on combustion and emissions characteristics of natural gas/diesel RCCI engine. Journal of Natural Gas Science and Engineering. 2015;25:58-65. 
[64] Liu J, Yang F, Wang H, Ouyang M. Numerical study of hydrogen addition to DME/CH4 dual fuel RCCI engine. International Journal of Hydrogen Energy 2012;37:8688-97.

[65] Benajes J, Pastor JV, García A, Monsalve-Serrano J. An experimental investigation on the influence of piston bowl geometry on RCCI performance and emissions in a heavy-duty engine. Energy Conversion and Management 2015;103:1019-39.

[66] Gharehghani A, Hosseini R, Mirsalim M, Jazayeri SA, Yusaf T. An experimental study on reactivity controlled compression ignition engine fueled with biodiesel/natural gas. Energy. 2015;89:558-67.

[67] Kalghatgi GT. The outlook for fuels for internal combustion engines. International Journal of Engine Research. 2014;15:383-98.

[68] Kamboj Sk, Kairimi MN. Effects of compression ratios, fuels and specific heats on the energy distribution in spark- ignition engine. International Journal of Emerging Technology and Advanced Engineering. 2012;2:482-91.

[69] Yakup, Altiparmak D. Effect of fuel cetane number and injection pressure on a DI Diesel engine performance and emissions. Energy Conversion and Management 2003;44:389-97.

[70] Paykani A, Kakaee A-H, Rahnama P, Reitz RD. Effects of diesel injection strategy on natural gas/diesel reactivity controlled compression ignition combustion. Energy. 2015;90:814-26.

[71] Aldawood A, Mosbach S, Kraft M. HCCI Combustion Control Using Dual-Fuel Approach: Experimental and Modeling Investigations. SAE Technical Paper No 2012-01-1117. 2012.

[72] Aldawood A, Mosbach S, Kraft M, Amer A. Dual-fuel effects on HCCI operating range: Experiments with primary reference fuels. SAE Technical Paper No 201301-1673. 2013.

[73] Maurya RK, Agarwal AK. Experimental investigation of close-loop control of HCCI engine using dual fuel approach. SAE 2013-01-1675. 2013.

[74] Ganesh D, Nagarajan. G. Homogeneous charge compression ignition (HCCI) combustion of diesel fuel with external mixture formation. Energy. 2010;35:14857.

[75] Liu H, Wang Z, Wang J, He X. Effects of gasoline research octane number on premixed low-temperature combustion of wide distillation fuel by gasoline/diesel blend. Fuel 2014;134:381-8.

[76] Cinar C, Uyumaz A, HamitSolmaz, Sahin F, Polat S, Yilmaz E. Effects of intake air temperature on combustion, performance and emission characteristics of a HCCI engine fueled with the blends of $20 \%$ n-heptane and $80 \%$ isooctane fuels. Fuel Processing Technology. 2015;130:275-81.

[77] Chun-hua Z, Jiang-ru P, Juan-juan T, Jing L. Effects of Intake Temperature and Excessive Air Coefficient on Combustion Characteristics and Emissions of HCCI. Procedia Environmental Sciences. 2011;11:1119-27.

[78] Maurya RK, Agarwal AK. Experimental investigation on the effect of intake air temperature and air-fuel ratio on cycle-to-cycle variations of HCCI combustion and performance parameters. Applied Energy. 2011;88:1153-63.

[79] Kumar P, Rehman A. Homogeneous Charge Compression Ignition (HCCI) Combustion Engine- A Review. IOSR Journal of Mechanical and Civil Engineering.2014;11(6):47-67. 
[80] Canakci M. Combustion characteristics of a DI-HCCI gasoline engine running at different boost pressures. Fuel. 2012;96:546-55.

[81] Canakci M. An experimental study for the effects of boost pressure on the performance and exhaust emissions of a DI-HCCI gasoline engine. Fuel. 2008;87:1503-14.

[82] You-cheng S, Min X, Yong G, Yi C, Lei S, Kang-yao D. Effects of injection pressure, exhaust gas recirculation and intake pressure on the cycle-to-cycle variations of HCCI combustion. Journal of the Energy Institute. 2016;89:293301.

[83] Li J, Yang WM, An H, Zhao D. Effects of fuel ratio and injection timing on gasoline/biodiesel fueled RCCI engine: A modeling study. Applied Energy. 2015;155:59-67.

[84] Benajes J, Molina S, García A, Monsalve-Serrano J. Effects of direct injection timing and blending ratio on RCCI combustion with different low reactivity fuels. Energy Conversion and Management. 2015;99:193-209. 